\title{
HAM DI MEJA HIJAU: SEBUAH REVIEW BUKU "PENGADILAN HAK ASASI MANUSIA DI INDONESIA, R. WIYONO" PRANADAMEDIA, JAKARTA 2015
}

\section{Yuwanda Tri Maryoga}

Mahasiswa Fakultas Hukum, Universitas Negeri Semarang

Surel:yogak3@students.unnes.ac.id

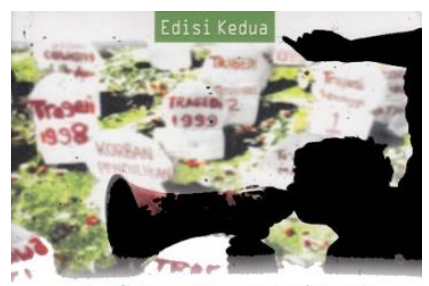

PENGADILAN HAK ASASI MANUSIA DI INDONESIA

R. Wiyono, S.H.

\author{
DATA BUKU \\ Judul Buku \\ : Pengadilan Hak Asasi Manusia \\ di Indonesia \\ Penulis : : W. Wiyono, S.H. \\ Penerbit : PRENADAMEDIA GROUP, \\ Tahun Terbit : : Februari 2015 \\ Kota Terbit : Jakarta \\ Bahasa Buku : Bahasa Indonesia \\ Jumlah Halaman : 239 \\ ISBN \\ : 978-602-7985-14-8
}

\section{RIWAYAT ARTIKEL}

Article History

Diterima 29 Maret 2017

Dipublikasi 20 November 2018

\section{KATA KUNCI}

Keywords

Hak Asasi Manusia, HAM,

Pengadilan HAM, Indonesia
HOW TO CITE (saran perujukan):

Maryoga, Y.T. (2018). "HAM di Meja Hijau: Sebuah Review Buku "Pengadilan Hak Asasi Manusia di Indonesia", R. Wiyono, Pranadamedia, Jakarta 2015", Lex Scientia Law Review. Volume 2 No. 2, November, hlm. 221-228.

BUKU yang ditulis oleh R. Wiyono, S.H. mengulas tentang pengadilan Hak Asasi Manusia di Indonesia, dengan pembahasan yang sederhana dan mudah dipahami membuat buku ini juga bisa dijadikan bacaan yang cukup bagus untuk masyarakat umum yang ingin mempelajari tentang pengadilan Hak Asasi Manusia Di lingkungan peradilan umum merupakan pengadilan di Indonesia yang paling banyak mendapat sorotan masyarakat, baik didalam negeri maupun diluar negeri. 
Sebagai pengadilan, pengadilan Hak Asasi manusia, dikatakan dalam awalan buku ini usaha untuk melindungi hak asasi manusia sudah diperdebatkan sejak waktu penyusunan Undang-Undang Dasar 1945 di BPUPKI, menurut HattaMuh. Yamin agar negara tidak menjadi negara kekuasaan maka Hak Asasi Manusia perlu dimasukan ke dalam Undang- Undang Dasar, sedangkan SoekarnoSoepomo negara hendak didirikan dengan paham kekeluargaan, sedangkan Hak Asasi Manusia buah dari paham individualisme sehingga Hak Asasi Manusia tidak dimasukan Undang-Undang Dasar. Hak Asasi Manusia yang dimuat dalam Undang-Undang Dasar 1945 juga mendahului Hak Asasi Manusia seperti yang dimuat dalam Universal Declaration of Human Right karena deklarasi ini juga baru berdiri pada tanggal 10 Desember 1948 ditetapkan disidang umum PPB di Paris.

Hak Asasi Manusia merupakan seperangkat hak yang melekat pada Hakikat dan keberadaan manusia sebagai makhluk Tuhan Yang Maha Esa dan merupakan anugerah-Nya yang wajib dihormati,dijunjung tinggi dan dilindungi oleh negara hukum, pemerintahan, dan setiap orang demi kehormatan serta perlindungan harkat dan martabat manusia dan pengadilan Hak Asasi Manusia merupakan pengadilan khusus yang berada di lingkungan peradilan umum yang menentukan dan berwenang memeriksa ataupun memutus perkara pelanggaran Hak Asasi Manusia yang berat saja. Buku yang hadir di hadapan para pembaca ini merupakan refleksi dan tuntuntan akademis dalam bidang pengadilan Hak Asasi Manusia yang ada di Indonesia yang diamanahkan negara kepada penulis untuk diajarkan, dikembangkan, dan dipublikasikan agar dapat memberikan manfaat.

Pada Bab 1 penulis menuliskan tentang pendahuluan yang isi tentang pengantar mengenai pengadilan Hak Asasi Manusia (HAM) di Indonesia. Kemudian pada Bab 2 menjelaskan mengenai apa itu Pengadilan HAM, pengertian, kemudian teori-teori. Lalu pada Bab 3 penulis menjelaskan mengenai lingkup kewenangan yang terdiri dari lingkup kewenangan absolut, lingkup kewenangan relatif, serta apa hubungan antara Mahkamah Pidana Internasional dengan Pengadilan HAM itu sendiri. Pada Bab 4 menjelaskan mengenai Hukum Acara yang meliputi penyelidikan, penyidikan, penuntutan, pemeriksaan disidang pengadilan, pelaksanaan putusan pengadilan. Lalu pada Bab 5 dijelaskan tentang penangkapan dan penahanan. Pada Bab 6 menjelaskan mengenai Pengadilan HAM ad hoc. Pada Bab 7 perlindunagn korban dan saksi dijelaskan pengertian, bentuk-bentuk perlindungan, tata cara pemberian perlindungan, serta pembiayaan. Lalu Bab 8 kompensasi, restitusi, dan rehabilitasi. Selanjutnya pada Bab 9 yaitu ketentuan pidana yang didalamnya menjelaskan kejahatan genosida serta kejahatan terhadap kemanusiaan. Dan yang terakhir pada Bab 10 penutup. Akar pengadilan Hak Asasi Manusia di Indonesia ternyata bisa menjadi bahasan yang panjang dan mendalam sehingga buku setebal 402 halaman itu bisa masih bisa diperpanjang 
lagi. Tulisan pengadilan Hak Asasi Manusiadi Indonesia akan lebih panjang lagi bila disertai dengan contoh kasusnya dan yang lain lain. secara singkat buku ini mendiskripsikan pentingnya pemahaman mengenai pengadilan Hak Asasi Manusia di Indonesia. Menariknya buku diawali dengan perumusan Hak Asasi Manusia yang dimulai ketika masa BPUPKI yang mana terdapat 2 golongan yang berbeda pendapat. Setelah ditetapkan Undang-Undang Dasar Negara Republik Indonesia 1945 berlaku kembali, baik zaman orda lama maupun orda baru, banyak dikeluarkan peraturan perundang-undangan yang isinya merupakan pelanggaran Hak Asasi Manusia, misal zaman orde lama telah dikeluarkan Ketetapan Presiden Nomor 7 Tahun 1959 tentang syarat-syarat dan penyederhanaan kepartaian dan Peraturan Presiden Nomor 13 Tahun 1960 tentang pengakuan, pengawasan, dan pembubaran.

Berikutnya dibuku menguraikan mengenai pengadilan Hak Asasi Manusia, pasal 1 angka 3 menentukan bahwa yang dimaksud dengan pengadilan Hak Asasi Manusia adalah pengadilan khusus terhadap pelanggaran Hak Asasi Manusia yang berat, yang berarti pengadilan Hak Asasi Manusia adalah pengadilan yang merupakan pengkhususan dari pengadilan lingkungan peradilan umum yang tugas dan wewenangnya hanya memeriksa dan memutus perkara pelanggaran Hak Asasi Manusia yang berat saja. Berarti pelanggaran yang kecil bukan merupakan pengadilan. Hak Asasi Manusia menurut saya, ada yang kurang mengenai penjelasan tersebut seharusnya penulis menambahkan pelanggaran yang tidak berat itu apa. Dalam buku ini juga terdapat banyak pasal pasal dan peraturan pemerintah yang terkait dengan dengan tindak pidana, hal ini memungkinkan para pembaca lebih mengetahui pasal apa yang mengaturnya dan peraturan pemerintah apa yang termuat.

Selanjutnya, penulis membahas tentang lingkup kewenangan, Hak Asasi Manusia disini terdapat dua lingkup kewenangannya yaitu, yang pertama lingkup kewenangan absolut, oleh pasal 4 ditentukan bahwa pengadilan Hak Asasi Manusia mempunyai tugas dan wewenang untuk memeriksa dan memutuskan perkara pelanggaran Hak Asasi Manusia yang berat, oleh pasal 7 pelanggaran Hak Asasi Manusia berat meliputi (kejahatan genosida dan kejahatan terhadap kemanusiaan). Dijelaskan juga tidak semua perkara pelanggaran Hak Asasi Manusia yang berat menjadi lingkup kewenangan absolut dari pengadilan Hak Asasi Manusia karena pasal 6 menentukan bahwa pengadilan Hak Asasi Manusia tidak berwenang memeriksa dan memutuskan perkara pelanggaran Hak Asasi Manusia yang berat oleh seseorang yang berumur dibawah 18 tahun dengan ketentuan pasal 26 Statuta Roma. Lingkup kewenangan yang kedua yaitu, lingkup kewenangan relatif adalah daerah hukum pengadilan Hak Asasi Manusia meliputi daerah hukum Pengadilan Negeri yang bersangkutan. 
Disini juga membahas hubungan antara mahkamah pidana internasional dengan pengadilan Hak Asasi Manusia, disertai dengan penjelasanya maka pembaca lebih mudah mengetahui apa maksud dari penjelasan tersebut. Disini juga membahas apa hubungan Mahkamah Pidana Internasional dengan pengadilan Hak Asasi Manusia , mengenai hubungan antara Mahkamah Pidana Internasional dengan pengadilan Hak Asasi Manusia dapat dilihat mukadimahnya yang menyatakan "international criminal court established under statue shall be complementary to national criminal jurisdiction" dari ketentuan tersebut dapat diketahui bahwa yurisdiksi dari Mahkamah Pidana Internasional merupakan pelengkap terhadap yurisdiksi dari Pidana Pengadilan Agama Internasional. Dengan demikian yurisdiksi Mahkamah Pidana Internasional baru dapat dilaksanakan, jika proses pengadilan yang efektif melalui tindakan hukum ditingkat nasional tidak dapat dilaksanakan.

Setelah membahas lingkup kewenangan, penulis membahas tentang Hukum acara, pengertian hukum acara, penyelidikan, pengertian penyelidikan, wewenangnya, pelaksanaanya, penyidikan, pengertian penyidikan, penyidik, wewenang penyidik, penuntutan, pengertian penuntutan, penuntutan umum, wewenang, pelaksanaaya, pemeriksaan sidang pengadilan, pemeriksaan tingkat pertama, pemeriksaan tingkat banding, pemeriksaan tingkat kasasi, peninjauan kembali, pelaksanaan putusan pengadilan, itu merukan meteri yang diangkat dalam bab ini. mengenai hukum acara yang berlaku atas perkara pelanggaran Hak Asasi Manusia yang berat, pasal 10 menentukan bahwa dalam hal tidak ditentukan lain dalam Undang-Tndang Nomor 26 Tahun 2000, hukum acara atas perkara pelanggaran Hak Asasi Manusia yang berat, dilakukan berdasarkan ketentuan Hukum Acara Pidana, dengan demikian, penyelidikan, penyidikan, penuntutan, pemeriksaan sidang pengadilan, upaya hukum, pelaksanaan putusan pengadilan serta pengawasan dan pengamatan pelaksanaan putusan atas perkara pelanggaran Hak Asasi Manusia yang berat, jika tidak ditentukan lain dalam Undang-Undang nomor 26 Tahun 2000, maka hukum acara atas pelanggaran Hak Asasi Manusia yang berat tersebut, dilakukan berdasarkan ketentuan hukum acara pidana.

Termasuk pula peraturan perundang-undangan atau produk hukum yang lain yang berkaitan atau yang merupakan penjabaran dari KUHAP, misalnya : 1) Peraturan Pemerintah Nomor 27 Tahun 1983 tentang pelaksanaan kitab UndangUndang Hukum Acara Pidana, 2) Keputusan Menteri Kehakiman RI Nomor M.14.PW.07.03 Tahun 1982 tentang pedoman pelaksanaan kitab Undang-Undang Hukum Acara Pidana, 3) Keputusan Menteri Kehakiman Republik Indonesia Nomor M.14.PW.07.03 Tahun 1983 tentang tambahan pedoman pelaksanaan 
kitab Undang-Undang Hukum Acara Pidana, dan 4) hasil REKERGAB MAKEHJAPOL.

Menurut Muladi, jika Undang Undang Nomor 26 Tahun 2000 dan KUHAP tidak mengatur, maka tidak ada salahnya jika atas dasar International Customary Law mengadopsi hal-hal yang diatur dalam statuta roma beserta segenap aturan dan prosedur sebagai lampirannya. Untuk selanjutnya yang akan diuraikan dan dibahas hanya ketentuan-ketentuan tentang hukum acara pidana yang terdapat didalam Undang-Undang Nomor 26 Tahun 2000, sedang yang terdapat dalam KUHAP akan diuraikan dan dibahas seperlunya saja, sebab sudah banyak bukubuku hukum acara pidana yang menguraikan dan membahas ketentuan-ketentuan yang terdapat dalam KUHAP.

Selanjutnya, penulis membahas penangkapan dan penahanan. Penangkapan karena tertangkap tangan, penangkapan, karena tidak tertangkap tangan, mengenai siapa yang berwenang melakukan penahan, siapa yang berhak melakukan tugas penangkapan merupakan salah satu materi yang ada dalam bab ini. Dijelaskan bahwa penangkapan, yaitu suatu tindakan penyidik berupa pengekangan sementara waktu kebebasan tersangka atau terdakwa apabila cukup bukti guna kepentingan penyidikan atau penuntutan dan peradilan dalam hal serta menurut cara yang diatur dalam Undang-undang Nomor 26 Tahun 2000. Sedangkan penahanan, yaitu penempatan tersangka atau terdakwa ditempat tertentu oleh penyidik, penuntutan umum atau hakim dengan penetapannya dalam hal serta menurut cara yang diatur dalam undang-undang Nomor 26 tahun 2000. Penangkapan karena tertangkap tangan yaitu penangkapan tanpa surat perintah, dengan ketentuan bahwa penangkapan harus segera menyerahkan tertangkap beserta barang bukti yang ada kepada penyidik. Penangkapan karena tidak tertangkap tangan, ditentukan bahwa Jaksa Agung sebagai penyidik mempunyai wewenang untuk melakukan penangkapan terhadap seseorang yang diduga keras melakukan pelanggaran Hak Asasi Manusia yang berat berdasarkan bukti pemulaan yang cukup.

Menurut penulis mengenai pengadilan Hak Asasi Manusia Ad Hoc dalam putusan Mahkamah Konstitusi Nomor 065/PUU-II/2004 terdapat pertimbangan hukum yang juga digunakan sebagai pertimbangan hukum putusan Mahkamah Konstitusi. Perlindungan korban dan saksi diterangkan peraturan umum pemerintah Nomor 2 tahun 2002 bahwa dengan jaminan perlindungan, diharapkan, baik korban maupun saksi dapat memberikan keterangan yang benar, sehingga prosesnya dapat dilaksanakan dengan baik, perlu diketahui perlindungan bagi para korban maupun saksi harus terjamin karena jika tidak maka kejahatan akan terus muncul dan para korban dan saksi akan terus merasa dirugikan, dari bentuk perlindungan tersebut diuraikan menjadi dua yaitu perlindungan atas keamanan pribadi korban atau saksi dari ancaman fisik dan mental, perahasian 
identitas korban atau saksi, pemberian keterangan pada saat pemeriksaan di sidang pengadilan tanpa bertatap muka dengan tersangka.

Dikatakan dalam buku ini dapat diketahui linkup kewenangan dari pengadilan Hak Asasi Manusia Ad Hoc yaitu lingkup kewenangan absolut sebagai berikut: a) memeriksa dan memutuskan pelanggaran Hak Asasi Manusia yang berat yang terjadi sebelum berlakunya Undang-Undang Nomor 26 Tahun 2000 pada Tanggal 26 September 2000, b) pelanggaran berat tersebut terbatas hanya yang terjadi pada tempat atau tempat-tempat dan waktu yang ditentukan dalam putusan Presiden tentang pembentukan pengadilan Hak Asasi Ad Hoc, sedangkan lingkup kewenangan relatif adalah seperti yang ditentukan dalam putusan Presiden tentang pembentukan pengadilan Hak Asasi Ad Hoc tersebut, didalam putusan Presiden tersebut ditentukan bahwa pengadilan Hak Asasi Manusia Ad Hoc pada pengadilan Negeri Jakarta Pusat mempunyai wewenang untuk memeriksa dan memutus perkara pelanggaran Hak Asasi Manusia yang berat terjadi di Timor Timur dalam wilayah hukum Liquica.

Selanjutnya penulis membahas tentang kompesensi, restitusi, dan rehabilitasi. Dalam hal ini yang mempunyai tugas atau kewajiban memberikan kompensasi, restitusi, dan rehabilitasi adalah instansi pemerintah terkait bertugas melaksanakan pemberian kompensasi dan rehabilitasi berdasarkan putusan pengadilan Hak Asasi Manusia yang telah memperoleh kekuatan hukum tetap, dalam hal kompensasi dan rehabilitasi menyangkut pembiayaan dan perhitungan keuangan negara, pelaksanaan dilakukan departemen keuangan. Restitusi adalah ganti rugi yang diberikan kepada korban atau keluarga oleh pelaku atau pihak ketiga, dapat berupa pengembalian harta milik pembayaran ganti kerugian untuk kehilangan atau penderitaan atau pengganti biaya. Pokok masalnya disini tentang bagaimana mengenai putusan Pengadilan Tinggi atau Mahkamah Agung yang memberikan kompensasi atau rehabilitasi apakah instansi Pemerintah terkait juga melaksanakan pemberian kompensasi atau rehabilitasi tersebut?

Selanjutnya penulis membahas ketentuan pidana, terdapat banyak pasal yang mengatur tentang ketentuan pidana, untuk membahas tentang ketentuan pidana tersebut perlu terlebih dahulu membahas pelanggaran HAM yang berat sebagaimana yang diatur dalam pasal 7 yaitu, genosida dan kejahatan terhadap kemanusiaan. Agar penafsiranya sama penulis memberlakukan pasal 6 dan 7 statuta roma. Hanya saja perlu diperhatikan bahwa dalam statuta roma terdapat perkecualian, yaitu tidak termasuk penyiksaan, jika sakit atau penderitaan itu melekat atau sebagai akibat dari sanksi yang sah. Oleh karenanya pasal 9 ayat 1 statuta roma menentukan bahwa unsur-unsur kejahatan membantu pengadilan menafsiran dan memberlakukan pasal 6 dan pasal 7 statuta roma, maka dengan sendirinya untuk menafsirkan dan memberlakukan ketentuan sebagaimana 
dimaksud dalam pasal 8 dan pasal 9 harus berpedoman pula pada "elenents of crimes" sebagaimana dimaksud dalam pasal 9 ayat 1 statuta roma.

Bagian terakhir yang disampaikan dalam pengadilan Hak Asasi Manusia di Indonesia, dijelaskan mengenai pasal 46-49, pasal 46 yang menyatakan untuk pelanggaran Hak Asasi Manusia yang berat sebagaimana yang dimaksud dalam undang-undang ini tidak berlaku ketentuan mengenai kadaluarsa. Sedangkan dalam buku ini pasal 47 menyatakan pelanggaran Hak Asasi Manusia yang berat yang terjadi sebelum berlakunya undang-undang ini tidak menutup kemungkinan menyelesaikan yang dilakukan oleh komisi kebenaran dan rekonsiliasi, jadi pelanggaran HAM yang berat yang terjadi sesudah berlakunya Undang-Undang Nomor 26 Tahun 2000 pada tanggal 23 November 2000 tidak dapat diselesaikan oleh komisi kebenaran dan rekonsiliasi.

Ada beberapa ungkapan yang diulang. Pada satu sisi buku ini dapat mengingatkan pembaca dengan ide-ide yang sedang dibahas. Pada sisi lain juga kadang-kadang membosankan. Misalnya pada Undang-Undang Nomor 26 tahun 2000 tentang maksud pelanggaran berat yaitu genosida dan kejahatan terhadap kemanusiaan, tampak akan lebih menarik jika diungkapkan secara sistematis sehingga ungkapannya tidak diulang meskipun dengan cara yang berbeda. Dengan bahasan yang cukup bagus dan konkrit membuat saya berpendapat bahwa buku ini cukup bagus dan bisa dijadikan referensi bagi siapapun. Penjelesan dan aturanaturan yang melengkapinya menjadikan semakin relevan untuk dibaca. Buku ini sangat berguna bagi mahasiswa ataupun aparat lembaga HAM dan juga masyarakat umum karena buku ini sudah bagus dan baik secara detail dan lengkap membahas tentang Hak Asasi Manusia. Namun pada poin-poin pembahasannya hanya dijelaskan secara umumnya saja tidak dijabarkan samapi akar-akarnya.

Manfaat apa yang dapat diambil dalam buku ini, hal yang paling utama adalah setelah membaca Pengadilan Hak Asasi Manusia di Indonesia adalah munculnya kesadaran tentang perlunya Hak Asasi Manusia untuk kehidupan sehari-hari. Kesadaran ini akan mengarahkan pembacanya untuk menjunjung tinggi nilai-nilai yang terkandung dalam Hak Asasi Manusia tanpa ada bentukbentuk tindakan yang melanggar Hak Asasi Manusia. Pada masa sekarang teknologi memberikan kemudahan untuk kita melakukan hal tersebut. Dimana kita dapat menelusuri serta mencari dan mengklarifikasi semua informasi-informasi factual dan actual yang ada disekitar kita, baik yang secara tertulis maupun yang tidak tertulis dengan menyaring (filter) informasi tersebut secara tepat dan bijaksana. Kemudian barulah bisa diterapkan menjadi sesuatu hal apa yang baik untuk ditanamkan, dilaksanakan maupun diapresiasikan dalam keseharian kita sebagai masyarakat yang taat dan bijak pada aturan hukum ditanah bangsa kita sendiri, Negara Kesatuan Repbulik Indonesia. 


\title{
Alterum Non Laedere
}

\author{
Perbuatanmu janganlah \\ merugikan orang lain
}

